\title{
Dermatologi med og uten professor
}

\author{
Når et medisinsk fakultet står uten professor i et klinisk fag, må man søke pragmatiske løsninger.
}

I 2009 sluttet den siste og eneste professoren i hudsykdommer ved Det medisinske fakultet, Universitetet i Oslo (1). Årsaken var at sykehuset ikke ville akseptere omfanget av hans avtalepraksis på fritiden omfanget var i strid med sykehusets interne regler om bierverv. Det ble gjort forsøk på å finne en minnelig løsning, blant annet å redusere hans overlegestilling til 50\% for å få «regnestykket til å gå opp». En slik løsning ble avvist av ledelsen. Resultatet ble at legen sluttet. Dermed sto Universitetet i Oslo uten professor i hudsykdommer for forste gang siden 1852. Legen driver nå avtalepraksis på fulltid.

Ett år senere opphevet styret i Helse SørØst retningslinjene for sykehusansattes bierverv og erstattet dem med nye (2). Vedtaket innebærer en tydelig liberalisering. Mens utgangspunktet tidligere var «å redusere det samlede omfanget og praktisere en restriktiv holdning», heter det nå at alle ansatte har «rett til fritt å disponere egen fritid», og at arbeidstakers adgang til å ta bierverv bare begrenses av lojalitetsplikt, habilitet og forsvarlig tjenesteutførelse (2). Det heter nå eksplisitt at virksomheter som omfattes av regionhelseforetakets sørge for-ansvar, ikke anses som motstridende forretningsmessige interesser. Dette gjelder bl.a. Feiring-klinikken og privat avtalepraksis.

Mindre enn ett år etter at Oslo-fakultetets eneste professor i hudsykdommer sluttet som følge av strenge regler for bierverv, mykes altså reglene opp. Nå er det for sent å reversere den omtalte oppsigelsen.

Hudavdelingen ved St. Olavs hospital i Trondheim, en mindre avdeling enn den i Oslo, har vært uten professor i mange år. Ledelsen har drevet et målrettet arbeid for å styrke avdelingens forskningsaktivitet. Med hele fem leger ved eller med tilknytning til avdelingen i gang med et doktorgradsprosjekt, savnet man en veileder med klinisk dermatologisk bakgrunn. Nå har avdelingen ansatt hudlegen som i 2009 sa opp sitt professorat i Oslo, i en midlertidig professor II-stilling med ansvar for veiledning og oppfølging av avdelingens forskningsstipendiater.

Ingen perfekt eller varig løsning, selvfølgelig, men langt bedre enn ingenting og langt bedre enn i Oslo, som fortsatt er uten en professor som kan inspirere og veilede unge forskere innen hudfaget. Det hadde norsk dermatologi trengt. I en vanskelig situasjon må man se etter løsninger, slik
Trondheim har gjort, og ikke bli låst av begrensninger. Et professorat i hudsykdommer i Oslo er nylig utlyst, men det er uvisst når en tilsetting kan skje.

\section{Petter Gjersvik \\ petjense@online.no \\ Observatorie terrasse $7 \mathrm{C}$}

0270 Oslo

Oppgitte interessekonflikter: Forfatteren er medlem av Forskningsutvalget i Norsk dermatologisk Selskap, førsteamanuensis i hudsykdommer ved Universitetet i Oslo og medisinsk redaktør i Tidsskriftet. Han har arbeidet sammen med omtalte professor på sykehus og i avtalepraksis iflere år.

\section{Litteratur \\ 1. Gjersvik P. Dermatologi uten professor. Tidsskr Nor Legeforen 2009; 129: 1122. \\ 2. Sak nr. 050-2010. Behandling av saker om ansattes bierverv i Helse Sør- Øst. Saksfremlegg for styret i Helse Sør- Øst 1.6. 2010. www.helse- sorost.no/modules/module_123/ proxy.asp?C $=126 \& \mid=1609 \& \bar{D}=2 \&$ mids $=$ \#Bistillinger (15.11.2010)}

Mottatt 15.11. 2010, godkjent 2.12. 2010. Medisinsk redaktør Anne Kveim Lie. 